ARTICLE

\title{
Anaemia and Mortality in Calves Caused by the Short-Nosed Sucking Louse (Haematopinus Eurysternus) (Nitzsch) in Ibadan
}

\author{
*LASISI, O.T' ${ }^{1}$ EYAREFE, O.D² and ADEJINMI, J.O³ \\ ${ }^{1}$ Department of Veterinary Medicine, University of Ibadan, Ibadan, Nigeria. ${ }^{2}$ Department of Veterinary Surgery and Reproduction, \\ University of Ibadan, Ibadan, Nigeria. ${ }^{3}$ Department of Veterinary Microbiology and Parasitology, University of Ibadan, Ibadan, Nigeria. \\ *Corresponding author: taiwolasisi@yahoo.com, taiwo-lasisi@hotmail.com
}

\begin{abstract}
SUMMARY
A cattle farm in lbadan recorded the death of a young calf with heavy infestation of short-nosed sucking louse, Haematopinus eurysternus. The surviving calves and calves on a second farm had mean packed cell volumes $(21.6 \pm 4.1$ and $24.6 \pm 1.8[\%])$, mean haemoglobin concentrations $(7.2 \pm 1.4$ and $8.3 \pm 0.6[\mathrm{~g} / \mathrm{dL}])$, and mean red blood cell counts $\left(6.3 \pm 0.7\right.$ and $\left.6.9 \pm 0.1\left[\times 10^{6} / \mathrm{L}\right]\right)$ which were below the reference ranges and consistent with anaemia. The animals were also heavily infested with lice. No other causes of anaemia were identified. After treating the calves with $1 \%$ ivermectin sub-cutaneously, all the red blood cell indices became significantly higher $(p \leq 0.05)$. It is therefore suggested that heavy infestations with $H$. eurysternus should be considered when investigating the cause of anaemia in calves in Nigeria.

KEYWORDS: Anaemia, Calves, Haematopinus eurysternus, Ibadan
\end{abstract}

\section{INTRODUCTION}

Ectoparasitic arthropods live on or burrow into, the surface of their host's epidermis for feed or shelter. As a result, they may cause direct damage to skin and other sub-cutaneous tissues (Tasawar et al., 2008). When present at high intensities, ectoparasites may cause harm indirectly, causing disturbance, increasing levels of behavior such as rubbing, leading to reduced time spent for grazing or ruminating and automutilation (Weeks et al., 1995).The ectoparasites have a major effect on the husbandry and productivity of livestock, weight gain (Devaney et al., 1992), milk production and quality of hides (Coles et al., 2003). They can cause harm due to their blood feeding activities and can transmit many pathogenic organisms
(Watson, 1984; Nafstad and Gronstol, 2001; Colwell and Himsl-Rayner, 2002).

The biting louse, Bovicola bovis, and three sucking louse species, Linognathus vituli, Solenopotes capillatus, and Haematopinus eurysternus, are widely prevalent in cattle (Lloyd, 1998; Otter, et al., 2003).

Cattle lice are considered by some cattle producers, veterinarians and veterinary entomologists to be underestimated in terms of economic losses suffered by cattle from these parasites, because treatment may not be initiated until cattle are rubbing, scratching and have an unkempt hair coat. However, these signs may not occur until much of the economic loss has already occurred (Campbell, 1988).

Louse infestations have been implicated in hide damage from rubbing (Baker and Oormadzi, 1978) and decreased weight gains in cattle (Gibney et al., 1985). Cattle lice can cause irritation, restlessness, and some studies suggest lice may be linked to a decrease in milk production and poor quality hides for harvest (Nafstad and Gronstol, 2001). Lice infestations cause the animal to scratch the areas infested, resulting in lesions or abrasions and areas of alopecia that can lead to bacterial or viral infections and insect infestations that cause the animal to become ill. A heavy load of lice may also cause the animal to become anaemic (Holdsworth et al., 2006).

Besides these performance losses, heavy louse infestations in cold weather may predispose cattle to stress-related illnesses such as respiratory disease (Campbell, 1988).

In Nigeria, there is a dearth of information on the 
systematic studies of louse infestation among breeds of cattle, although Otesile and Obasaju, (1980) carried out a survey of ectoparsites of sheep and goats in Ibadan, Nigeria.

This work was carried out to investigate death of a young calf on a farm, where heavy infestations with $H$. eurysternus were associated with anaemia in other calves. Calves on a second farm were also anaemic, in association with a heavy infestation of this louse species.

\section{Materials and Methods}

Blood samples were taken into bijou bottles containing disodium ethylene diamine tetra acetic acid $\left(\mathrm{Na}_{2}\right.$ EDTA $)$ as anticoagulant and examined haematologically on a pocH-100iV Diff (Sysmex Animal health); the normal reference ranges for the haematological parameters have been derived from Radostits et al. (2000)

The louse populations were evaluated by a method similar to that described by Colwell et al. (2001): the number of live lice were counted on each animal. Lice were identified to species and counted at each of nine known predilection sites. The following sites, with dimensions of the area, were examined: topline (mid-dorsal surface, midway between the withers and the pelvis) (5 $\mathrm{cm} \times 15 \mathrm{~cm})$, withers $(5 \mathrm{~cm} \times 15 \mathrm{~cm})$, around each eye ( $5 \mathrm{~cm}$ zone around eye margin), right and left cheek $(5 \mathrm{~cm} \times 10 \mathrm{~cm})$, muzzle $(5 \mathrm{~cm} \times$ $25 \mathrm{~cm})$ and dewlap $(5 \mathrm{~cm} \times 15 \mathrm{~cm})$. Also the tail brush $(5 \mathrm{~cm} \times 15 \mathrm{~cm})$ was examined for the presence of lice on the cattle. Live lice were counted by using a hair-parting technique to expose the skin over the entire area within a region. Samples of lice were removed and placed in vials of $70 \%$ alcohol for subsequent identification. The lice examination sites were chosen because each louse species tends to be found most often on specific areas of an animal (Watson et al., 1997).

Age of each animal was estimated based on the method described by Lasisi et al., (2002). All data were subject to Student's t-test.

\section{Case Descriptions}

\section{Postmortem examination and farm} investigations

This investigation was carried out on two different farms located at the suburbs of Ibadan, Nigeria.

Farm 1: In February 2005, the carcass of an eight-month old Sokoto Gudali calf from a semiintensive 30-cow farm was examined. The adult animals were within the age range of $2 \frac{1}{2}$ to 4 years. It was from a group of eight similarly aged calves that had not been previously examined by a veterinarian. Their diet consisted of concentrates and cut grasses both fed ad libitum, and water. The calf was not in a good body condition, with generalized pallor of mucous membranes and some level of dehydration, and a heavy louse infestation. The lice were numerous around the eye-lids, around the neck, at the base of the ears and tail brush. No other abnormalities were observed. The lice were identified as a mixed population of Haematopinus eurysternus and Linognathus vituli, present in a ratio of approximately ten $H$. eurysternus to one $L$. vituli.

The remaining seven calves in the group were in poor body condition and were heavily infested with lice, like the calf examined postmortem. Two of the calves (calves 1 and 2) (Table I) were depressed, dehydrated, weak and spent most of their time lying down. Their tail brush showed typical cemented eggs of lice, but pruritus was not observed. The other five calves (calves 3 to 7) stood with limited movement within the area of space where they were tied. The packed-cell volume (PCV), haemoglobin concentration and red blood cell (RBC) count of the calves were presented (Table I). All the seven calves were treated with $1 \%$ ivermectin sub-cutaneous injection (Ivomec Super ${ }^{\mathrm{R}}$ Merial Animal Health, Germany) at dose rate of $0.2 \mathrm{mg}$ per $\mathrm{kg}$ body weight. One month later, no mortality was recorded after treatment and all the calves were brighter and more active with haematological values being normal (Table II); no lice were seen in any of them and the treatment was repeated.

Farm 2: In May 2006, a farmer complained of lack of growth among his calves of about eight months old. The farm consisted of 20 cows, 3 bulls and 6 calves of both sexes and the breeds were Sokoto Gudali, Red Bororo, White Fulani and Crosses of Sokoto Gudali and White Fulani. On visit to the farm, the calves were housed in several pens and fed with concentrates, 
groundnut husk meal and water. The animals were not initially given any medication. Seven of the calves were examined, and were found to be heavily infested with $H$. eurysternus, with no other skin lesions observed. The mucous membranes of eyes and perineum areas were pale. Feces examined by the modified McMaster technique contained a mean value of $6,360 \pm 3.5$ coccidial oocysts per gramme but with no helminth worm eggs and no diarrhea or enteritis. Blood samples of all the calves were taken into Bijou bottles with disodium ethylene

diamine tetra acetic acid $\left(\mathrm{Na}_{2}\right.$ EDTA $)$ as anticoagulant. The mean PCV, haemoglobin and $\mathrm{RBC}$ values were lower than normal ranges (Table III).One and a half months later, the calves started gaining weight with improved haematological parameters after treatment with $1 \%$ ivermectin sub-cutaneous injection (Ivomec Super ${ }^{\mathrm{R}}$ Merial Animal Health, Germany) (Table IV).

\section{RESULTS}

Table l: Haematological results for the group of seven calves on farm 1 in February 2005

\begin{tabular}{|c|c|c|c|c|c|c|c|c|c|}
\hline \multirow[t]{2}{*}{ Variable } & \multirow{2}{*}{$\begin{array}{l}\text { Reference range } \\
\text { (Radostits et al. 2000) }\end{array}$} & \multicolumn{6}{|c|}{ Calf } & \multirow{2}{*}{\multicolumn{2}{|c|}{${ }_{7}$ Mean Value \pm SD }} \\
\hline & & 1 & 2 & 3 & 4 & 5 & 6 & & \\
\hline $\mathrm{PCV}(\%)$ & $24-46$ & 17 & 26 & 18 & 22 & 27 & 20 & 25 & $21.6 \pm 4.1^{a}$ \\
\hline Haemoglobin(g/dL) & 8-15 & 5.8 & 8.7 & 5.8 & 7.2 & 9.0 & 6.6 & 8.0 & $7.2 \pm 1.4^{b}$ \\
\hline $\operatorname{RBC}\left(x 10^{6} / L\right)$ & $5-10$ & 6.3 & 6.3 & 5.2 & 6.5 & 7.4 & 5.8 & 6.0 & $6.3 \pm 0.7^{c}$ \\
\hline $\operatorname{MCV}(f l)$ & $40-60$ & 26 & 41 & 34 & 33 & 36 & 34 & 41 & $34.0 \pm 4.9$ \\
\hline $\mathrm{MCH}(\mathrm{pg})$ & $11-17$ & 10 & 13 & 11 & 11 & 12 & 11 & 13 & $11.3 \pm 1.0$ \\
\hline $\mathrm{MCHC}(\mathrm{g} / \mathrm{dl})$ & $20-30$ & 34 & 33 & 32 & 32 & 33 & 33 & 32 & $32.8 \pm 0.8$ \\
\hline
\end{tabular}

Table II: Haematological results for the group of seven calves on farm 1 in April 2005

\begin{tabular}{|c|c|c|c|c|c|c|c|c|c|}
\hline \multirow[t]{2}{*}{ Variable } & \multirow{2}{*}{$\begin{array}{l}\text { Reference range } \\
\text { (Radostits et al. 2000) }\end{array}$} & \multicolumn{7}{|c|}{ Calf } & \multirow[t]{2}{*}{ Mean Value $\pm S D$} \\
\hline & & 1 & 2 & 3 & 4 & 5 & 6 & 7 & \\
\hline PCV $(\%)$ & $24-46$ & 29 & 34 & 30 & 30 & 35 & 30 & 29 & $31.3 \pm 2.5^{\mathrm{d}}$ \\
\hline Haemoglobin(g/dL) & $8-15$ & 9.6 & 11.1 & 9.9 & 9.9 & 11.7 & 10.0 & 9.8 & $10.4 \pm 0.8^{e}$ \\
\hline $\operatorname{RBC}\left(\times 10^{6} / \mathrm{L}\right)$ & $5-10$ & 8.2 & 9.5 & 8.7 & 10.2 & 10.5 & 8.70 & 8.70 & $9.2 \pm 0.9^{f}$ \\
\hline $\mathrm{MCV}(\mathrm{fl})$ & $40-60$ & 35 & 35 & 34 & 29 & 32 & 34 & 33 & $33.2 \pm 2.3$ \\
\hline $\mathrm{MCH}(\mathrm{pg})$ & $11-17$ & 11 & 11 & 11 & 09 & 10 & 11 & 11 & $10.5 \pm 0.8$ \\
\hline $\mathrm{MCHC}(\mathrm{g} / \mathrm{dl})$ & $20-30$ & 33 & 32 & 33 & 33 & 33 & 33 & 33 & $32.8 \pm 0.4$ \\
\hline
\end{tabular}

Table III: Haematological results for the group of six calves on farm 2 in May 2006

\begin{tabular}{|lllllllll|}
\hline Variable & $\begin{array}{l}\text { Reference range } \\
\text { (Radostits et al. 2000) }\end{array}$ & $\mathbf{1}$ & $\mathbf{2}$ & $\mathbf{3}$ & $\mathbf{4}$ & $\mathbf{5}$ & $\mathbf{6}$ & Mean Value $\mathbf{\pm S D}$ \\
\hline $\mathrm{PCV}(\%)$ & $24-46$ & 24 & 27 & 23 & 26 & 23 & 22 & $24.6 \pm 1.8^{9}$ \\
Haemoglobin $(\mathrm{g} / \mathrm{dL})$ & $8-15$ & 8.0 & 9.0 & 7.8 & 8.9 & 7.7 & 7.3 & $8.3 \pm 0.6^{\mathrm{h}}$ \\
$\mathrm{RBC}\left(\mathrm{x} 10^{6} / \mathrm{L}\right)$ & $5-10$ & 7.0 & 6.8 & 6.9 & 6.8 & 6.8 & 5.8 & $6.9 \pm 0.1^{\mathrm{i}}$ \\
$\mathrm{MCV}(\mathrm{fl})$ & $40-60$ & 34 & 39 & 33 & 38 & 33 & 34 & $35.4 \pm 2.9$ \\
$\mathrm{MCH}(\mathrm{pg})$ & $11-17$ & 11 & 13 & 11 & 13 & 11 & 12 & $11.8 \pm 1.1$ \\
\hline $\mathrm{MCHC}(\mathbf{g} / \mathrm{dl})$ & $\mathbf{2 0 - 3 0}$ & $\mathbf{3 3}$ & $\mathbf{3 3}$ & $\mathbf{3 3}$ & $\mathbf{3 4}$ & $\mathbf{3 3}$ & $\mathbf{3 3}$ & $\mathbf{3 3 . 2 \pm 0 . 4}$ \\
\hline
\end{tabular}

PCV: Packed Cell Volume, RBC: Red blood cell, MCV: Mean Cell volume, MCH: Mean Cell Haemoglobin, MCHC: Mean Cell Haemoglobin Concentration.

Mean values with same superscripts are not significantly different 
Nigerian Veterinary Journal 2010 3I(4)

Table IV: Haematological results for the group of six calves on farm 2 in July 2006

\begin{tabular}{|c|c|c|c|c|c|c|c|c|}
\hline \multirow[t]{2}{*}{ Variable } & \multirow{2}{*}{$\begin{array}{l}\text { Reference range } \\
\text { (Radostits et al. 2000) }\end{array}$} & \multicolumn{5}{|c|}{ Calf } & \multirow[b]{2}{*}{6} & \multirow[b]{2}{*}{ Mean Value \pm SD } \\
\hline & & 1 & 2 & 3 & 4 & 5 & & \\
\hline $\mathrm{PCV}(\%)$ & $24-46$ & 30 & 35 & 40 & 42 & 29 & 28 & $35.2 \pm 5.8^{j}$ \\
\hline Haemoglobin(g/dL) & $8-15$ & 9.9 & 11.7 & 13.2 & 14.8 & 8.9 & 9.4 & $11.7 \pm 2.4^{\mathrm{k}}$ \\
\hline $\mathrm{RBC}\left(\times 10^{6} / \mathrm{L}\right)$ & $5-10$ & 8.5 & 12.6 & 12.8 & 12.9 & 8.5 & 6.9 & $11.1 \pm 2.3^{\prime}$ \\
\hline $\operatorname{MCV}(\mathrm{fl})$ & $40-60$ & 40 & 27 & 31 & 32 & 34 & 40 & $32.8 \pm 4.7$ \\
\hline $\mathrm{MCH}(\mathrm{pg})$ & $11-17$ & 11 & 09 & 10 & 10 & 10 & 13 & $10.0 \pm 0.7$ \\
\hline $\mathrm{MCHC}(\mathrm{g} / \mathrm{dl})$ & $20-30$ & 33 & 33 & 34 & 33 & 30 & 33 & $32.6 \pm 1.5$ \\
\hline
\end{tabular}

PCV: Packed Cell Volume, RBC: Red blood cell, MCV: Mean Cell volume, MCH: Mean Cell Haemoglobin, MCHC: Mean Cell Haemoglobin Concentration.

Mean values with same superscripts are not significantly different

\section{DISCUSSION}

The dead calf examined postmortem was a pale carcass and was heavily infested with $H$. eurysternus. In addition, all the calves in both farms had low PCV, haemoglobin and RBC values (Tables I and III). The haematological results are consistent with anaemia as defined by Radostits et al. (2000). According to these workers, there are many causes of anaemia in calves, but in these cases, the clinical histories, post-mortem findings, haemato-logical results and the response of the calves to treatment with ectoparasiticide, the heavy burdens of sucking lice were considered to be the most likely cause of the anaemia in the calves. Since haemo-globin accounts for more than $90 \%$ of the protein within erythrocytes ( Quigley et al., 2004 ), its concentration values among all the calves were below normal, therefore this explains why the animals were not gaining weight as a result of heavy lice infestation.

Infestations with $H$. eurysternus are more common in calves than in mature animals (Otter et al., 2003; Geden et al., 1990), a finding that is consistent with the age distribution of the affected calves. In the work of Watson et al. (1997), in terms of spatial distribution, $H$. eurysternus was found to be next to Bovicola bovis, a finding that is similar to the distribution of $H$. eurysternus in the present investigation.

Since lice infestations are generally more severe in undernourished calves (Cummins and Graham, 1982), it was not unlikely that undernourishment was a predisposing factor to the heavy infestations observed in theses two farms visited because the major constraints to increased livestock production in Nigeria include inadequate nutrition (quantitative and qualitative) (Obi, 1997).

On farm 2, it is possible that coccidiosis, which was not likely to have been the primary cause of anaemia observed (it is not a major problem in cattle but in poultry), may have predisposed the calves to heavier louse infestation. Coccidiosis in calves is generally characterized by watery diarrhea as a result of intestinal damage (Kaplan, 2004). On the first farm, no other diseases were identified.

On both farms, the finding that Sokoto Gudali breed and its crosses were the most affected groups of calves, is not consistent with the earlier work of Watson et al. (1997) in which breed or cross breed differences were not taken into consideration while studying the density and distribution of four types of lice on steers.

The optimal effects of the injectable treatments observed in this study against sucking lice are generally consistent with results of other studies that evaluated effects of injectable formulations of macrocyclic lactones (Skogerboe et al., 2000; Polley et al., 1998).

Therefore, when cattle and their calves are observed to have slow growth and reduced weight gains, infestations with ectoparasites need to be considered. The use of macrocyclic lactones can also be of great help during infestation with sucking lice for optimal productivity of our animals.

\section{REFERENCES}

BAKER, K.P. and OORMADZI, H. (1978): The probable cause of the multiple linear scratch 
defect of cattle hides in Ireland. Soc. Leath. Technol. Chem., 62, 103-107.

CAMPBELL, J.B., (1988): Arthropod-induced stress in livestock. Vet. Clinics N. Am. Food Anim. Pract., 4, 551-555.

COLES, G. C., P. J. HADLEY, A. S. MILNES, L. E. GREEN, P. J. STOSIC and P.C. GARNSWORTHY, (2003): Relationship between lice infestation and leather damage in cattle. Vet. Rec., 153, 255-259

COLWELL, D. D. and C. HIMSL-RAYNER, (2002): Linognathus vituli (Anoplura: Linognathidae): population growth, dispersal and development of humoral immune responses in naive calves following induced infestation. Vet. Parasitol., 108, 237-246.

COLWELL, D.D., CLYMER, B., BOOKER, C.W., GUICHON, T., JIM, G.K., SCHUNICHT, O.C and WILDMAN, B.K. (2001).Prevalence of sucking and chewing lice on cattle entering feedlots in southern Alberta. Can. Vet. J., 42, 281-285.

CUMMINGS, L.J AND GRAHAM, J.F (1982): The effect of lice infestation on the growth of Hereford calves. Aust. Vet. J., 58, 194-196

DEVANEY, J. A., CRAIG, T. M. ROWE, L. D. WADE, C. and MILLER, D. K. (1992): Effects of low levels of lice and internal nematodes on weight gain and blood parameters in calves in central Texas. $J$. Econ. Entomol., 85: 144-149.

GEDEN, C.J., RUTZ, D.A. and BISHOP, D.R., (1990): Cattle lice (Anoplura, Mallophaga) in NewYork: seasonal population changes, effects of housing type on infestations of calves, and sampling efficiency. J. Econ. Entomol., 83, 1435-1438.

GIBNEY, V.J., CAMPBELL, J.B., BOXLER, D.J., CLANTON, D.C. and DEUTSCHER, G.H., (1985): Effects of various infestation levels of cattle lice (Mallophaga: Trichodectidae and Anoplura: Haematopinidae) on feed efficiency and weight gains of beef heifers. J. Econ. Entomol., 78, 1304-1307.

HOLDSWORTH PA, VERCRUYSSE J, REHBEIN S. PETER R.J, LETONJA T, and GREEN P. (2006): World Association for the Advancement of Veterinary Parasitology (W.A.A.V.P) guidelines for evaluating the efficacy of ectoparasiticides against biting lice, sucking lice and sheep keds on ruminants. Vet. Parasitol., 136, 45-54.

KAPLAN, R. M. (2004): Drug resistance in nematodes of veterinary importance: a status report. Trends Parasitol., 20, 477-81.

LASISI, O. T., OJO, N. A. and OTESILE, E. B. (2002):
Estimation of age of cattle in Nigeria using rostral dentition. Trop. Vet., 20, 204-208.

LLOYD, J.E. (1998): Lice infestation (pediculosis). Curr. Vet. Ther., 4, 707-710.

NAFSTAD, O. and GRONSTOL, H.(2001): Eradication of lice in cattle. Acta Vet. Scand., 42, 81-89.

OBI, T.U.(1997): Non-parasitic livestock diseases in Nigeria: An overview. Trop. Vet., 15, 85-95.

OTESILE, E.B and OBASAJU, M.F. (1980): Survey of ectoparasites of sheep and goats in Ibadan, Nigeria. Nig. J. Parasitol., 1, 79-88.

OTTER, A., TWOMEY, D. F., CRAWSHAW, T. R. and BATES, P. (2003): Anaemia and mortality in calves infested with the long-nosed sucking louse (Linognathus vituli). Vet Rec., 153, 176-179

QUIGLEY, J. G. , YANG , Z. , WORTHINGTON , M. T. , PHILLIPS , J. D. , SABO , K. M. , SABATH , D. E. , BERG , C. L. , SASSA , S. , WOOD , B. L., and ABKOWITZ , J. L. (2004): Identification of a human heme exporter that is essential for erythropoiesis. Cell, 118, 757-766.

RADOSTITS, O.M., GAY, C.C., BLOOD, D.C. AND HINCHCLIFF, K.W. (2000): Veterinary Medicine, 9th ed., W.B. Saunders, London, pp. 1819-1822

POLLEY, L.R., WAGNER, B.A., WARD, T.I. and CAMPBELL, J.R. (1998): Effect of topical ivermectin and moxidectin for naturally acquired Damalinia bovis infestations in cattle treated under winter conditions in Canada. Vet. Rec., 143, 80-81.

SKOGERBOE T.L, SMITH L.L, KARLE V.K and DEROZIER C.L. (2000): The persistent efficacy of doramectin pour-on against biting and sucking louse infestations of cattle. Vet Parasitol., 87,183192.

TASAWAR, Z., BANO,I., HAYAT, S and LASHARI, M. H. (2008): Prevalence of lice on buffaloes at private cattle farm. Pakistan Vet. J., 28 (3): 147-149

WATSON, D.W. (1984): The dynamics and distribution of cattle lice populations on naturally infested steers. M.S. Thesis, University of Wyoming. $127 \mathrm{pp}$.

WATSON, D.W., LLOYD, J.E. and KUMAR, R. (1997): Density and distribution of cattle lice (Phthiroptera: Haematopinidae Linognathidae Trichodectidae) on six steers. Vet. Parasitol., 69, 283-296.

WEEKS, C. A., NICOL, C. J. and TITCHENER, R. N. (1995): Effects of the sucking louse (Linognathus vituli) on the grooming behavior of housed calves. Vet. Rec., 137, 33-35. 